\title{
PENGARUH KUALITAS PELAYANAN, KUALITAS PRODUK, DAN INOVASI PRODUK TERHADAP KEPUASAN UNTUK MENINGKATKAN LOYALITAS PELANGGAN
}

\author{
Muhammad Ryan Fauzi ${ }^{1}$ \\ Kastawan Mandala ${ }^{2}$
}

\author{
${ }^{1,2}$ Fakultas Ekonomi dan Bisnis Universitas Udayana, Bali, Indonesia \\ email: ryanfauzi9e40@gmail.com ${ }^{1}$
}

\begin{abstract}
ABSTRAK
Kepuasan pelanggan merupakan faktor penting dalam menumbuhkan loyalitas pelanggan serta upaya yang tepat untuk menciptakan pengembangan perusahaan dalam jangka panjang. Kepuasan dapat tercipta ketika perusahaan berhasil memenuhi harapan dari konsumen yang kemudian akan menurunkan peluang keinginan pelanggan untuk beralih ke produk atau perusahaan lain, sehingga loyalitas pelanggan juga dapat terbentuk. Tujuan penelitian ini untuk menjelaskan pengaruh kualitas pelayanan, kualitas produk, dan inovasi produk terhadap kepuasan untuk meningkatkan loyalitas pelanggan. Penelitian ini dilakukan pada pelanggan CV. Bintang Harapan Kurnia di Kota Denpasar. Populasi sampel yang diambil sebanyak 100 responden, dengan metode purposive sampling. Pengumpulan data dilakukan melalui penyebaran kuesioner. Teknik analisis data yang digunakan adalah PLS versi 3.0. Berdasarkan hasil analisis, ditemukan bahwa kualitas pelayanan, kualitas produk, dan inovasi produk berpengaruh positif signifikan terhadap kepuasan pelanggan, dan kepuasan pelanggan berpengaruh positif signifikan terhadap loyalitas konsumen. Implikasi teoretis yang diperoleh adalah berupa kontribusi teori mengenai loyalitas pelanggan khususnya dalam hal komitmen, pembelian ulang, dan pemberian rekomendasi kepada pelanggan lain, sedangkan implikasi praktisnya untuk memberikan evaluasi terhadap perusahaan untuk dapat meningkatkan kualitas pelayanan, kualitas produk, serta inovasi produk agar dapat meningkatkan kepuasan pelanggan yang kemudian akan meningkatkan loyalitas pelanggan.
\end{abstract}

Kata Kunci: kualitas pelayanan, kualitas produk, inovasi produk, kepuasan pelanggan, loyalitas pelanggan.

\begin{abstract}
Customer satisfaction is an important factor in building customer loyalty as well as in the company's long-term development efforts. Creating satisfied consumers can done by fulfilling the expectations of consumers which can then hinder the consumer's desire to switch to another product or company, so that customer loyalty can also be formed. The purpose of this study is to explain the effect of service quality, product quality, and product innovation on satisfaction to increase consumer loyalty. This research was conducted on CV Bintang Harapan Kurnia customers in Denpasar. The sample population was taken as many as 100 respondents, with a purposive sampling method. Data collection is done through questionnaires. The data analysis technique used is PLS version 3.0. Based on the results of the analysis, it was found that service quality, product quality, and product innovation had a significant positive effect on customer satisfaction, and customer satisfaction had a significant positive effect on consumer loyalty. The theoretical implications obtained are in the form of theoretical contributions regarding customer loyalty, especially in terms of commitment, repurchase, and giving recommendations to other customers, while the practical implications are to provide evaluations to companies to improve service quality, product quality, and product innovation.
\end{abstract}

Keywords: service quality, product quality, product innovation, customer satisfaction, customer loyalty. 


\section{PENDAHULUAN}

Pertumbuhan industri konveksi di Indonesia menyebabkan semakin ketatnya persaingan yang mengharuskan perusahaan untuk memiliki keunggulan bersaing. Keunggulan bersaing dapat diperoleh ketika perusahaan memiliki konsumen yang loyal terhadap perusahaan. Loyalitas pelanggan merupakan sikap positif yang dibentuk konsumen terhadap merk yang telah digunakan. Sikap positif ini juga merupakan bentuk komitmen pelanggan terhadap merk sehingga akan timbul keinginan atau maksud untuk meneruskan pembelian di masa mendatang. Loyalitas pelanggan terbentuk ketika pelanggan merasa puas dengan produk yang telah dikonsumsi dari perusahaan tersebut.

Kepuasan pelanggan merupakan bentuk perasaan timbul oleh karena apa yang diekspektasikan oleh pelanggan dirasakan pada sebuah produk yang kemudian dapat menurunkan peluang keinginannya untuk beralih ke produk maupun ke perusahaan lainnya. Kepuasan pelanggan tersebut dapat terbentuk melalui kualitas pelayanan yang mana dapat berupa kualitas pelayanan yang dinilai secara visual oleh konsumen (fisik), dapat pula berupa keberhasilan pelayanan sesuai dengan kebutuhan konsumen, fungsi, dan nilai yang diharapkan oleh konsumen (keandalan), kesigapan karyawan dalam pemberian layanan (tanggap), adanya jaminan bahwa informasi yang diberikan pada saat pelayanan adalah benar (jaminan), serta adanya keinginan membantu yang timbul ketika konsumen merasa kesulitan baik dalam memutuskan pembelian maupun ketika konsumen kesulitan dalam hal lainnya menyangkut produk (empati). Kualitas pelayanan ini dapat berdampak pada rasa nyaman, aman, dan keinginan konsumen untuk tidak berpindah yang mana kualitas ini juga harus diimbangi dengan kualitas produk yang ditawarkan perusahaan.

Kualitas produk menyangkut keadaan fisik, fungsi, serta sifat produk yang memenuhi kebutuhan konsumen berupa selera dan harapan terhadap produk dibandingkan dengan nilai uang yang bersedia dikeluarkan oleh konsumen untuk memperoleh produk tersebut. Kualitas ini yang membawa konsumen pada keputusan akan tetap menggunakan produk atau mencari produk pengganti yang lebih mendekati ekspektasi konsumen. Apabila perusahaan mampu memberikan kualitas produk yang dapat memenuhi ekspektasi konsumen maka dampaknya adalah pada keunggulan bersaing perusahaan tersebut. Namun keberadaan suatu produk tidak selamanya dapat menjawab kebutuhan dan memberikan solusi pada konsumen yang dinamis dan terus berkembang sehingga perusahaan membutuhkan inovasi dalam menjaga hubungan positif dengan konsumen yang selalu berubah mengikuti perubahan dunia.

Inovasi produk merupakan sumber pertumbuhan perusahaan karena perubahan-perubahan tersebut berasal dari hasil evaluasi perusahaan terhadap kualitas poduk yang dimiliki agar tetap mampu mengikuti perkembangan selera dan kebutuhan konsumen. Inovasi produk dapat meningkatkan nilai tambah produk serta dapat memberikan solusi dari sejumlah kebutuhan yang dibutuhkan konsumen pada satu produk atau solusi atas evaluasi terhadap produk lama. Adanya inovasi ini maka aka nada perbaikan kualitas secara terus menerus sehingga konsumen akan merasa lebih puas dan enggan untuk berpindah ke produk atau perusahaan lainnya. 
Kualitas layanan merupakan konsep dari kerangka strategi pemasaran dengan fokus pemikiran bahwa pelanggan memiliki harapan dan perusahaan berupaya dalam mengimbangi haapan tersebut dengan mewujudkan pemenuhan kebutuhan dan keinginan pelanggan (Tefera \& Govender, 2017;Familiar \& Ida Maftukhah, 2015). Kualitas pelayanan yang ideal adalah ketika pelayanan yang diterima melampaui harapan konsumen dan sebaliknya apabila pelayanan yang diterima lebih rendah dari yang diharapkan maka kualitas pelayanan dianggap buruk (Tjiptono, 2006). Kualitas pelayanan memiliki lima dimensi yaitu tangibles (merupakan bukti langsung yang dapat secara langsung dinilai melalui visual atau tampilan dari fasilitas fisik), reliability (merupakan dimensi kesamaan atau sesuai tidaknya pelayanan yang diberikan terhadap apa yang dijanjikan kepada pelanggan baik dengan pemberian informasi yang sesuai hingga bentuk pelayanan yang handal), responsiveness (merupakan bentuk kesediaan karyawan dalam memberikan pelayanan kepada konsumen), assurance (merupakan dimensi yang dapat memberikan jaminan atau rasa aman kepada konsumen sehingga akan menumbuhkan rasa percaya terhadap perusahaan), dan empathy (merupakan dimensi kesediaan perusahaan untuk memperhatikan kebutuhan konsumen dan kesediaan dalam memberi kemudan atau bantuan ketika konsumen mengalami permasalahan baik sebelum maupun setelah mengkonsumsi produk yang ditawarkan perusahaan) (Putro dkk., 2014).

Produk merupakan segala sesuatu yang yang diperjualbelikan ke pasar atau telah melalui proses penawaran dan permintaan guna dikonsumsi agar dapat memenuhi keinginan dan kebutuhan pelanggan. Adapun indikator kualitas produk menurut Schiffman \& Kanuk, (2006) yaitu merupakan produk yang popular, produk yang berkualitas, produk yang bermanfaat, serta produk yang memiliki variasi. Kualitas produk dapat dinilai dengan acuan yaitu Lovelock \& Wright L., (2005) : (a) Performance (kinerja), yaitu karakteristik suatu produk yang penilaian kualitasnya meliputi kemampuan suatu produk dalam menjalankan fungsi utamanya dengan optimal/baik. (b) Features (tampilan), yaitu dimensi tampilan yang meliputi ciri-ciri tambahan yang melengkapi manfaat dasar dari produk tersebut yang mana dimensi ini bersifat pilihan (optional) tergantung pada keinginan dan kebutuhan konsumen serta ditambahkan jika manfaat utama produk telah memenuhi standar. (b) Reliability (kehandalan), yaitu dimensi peluang keberhasilan atau peluang bebasnya produk dari kegagalan selama menjalankan fungsinya. (c) Conformance (kesesuaian), yaitu dimensi kesesuaian yang memberikan penilaian bahwa kualitas yang baik adalah ketika kinerja produk sesuai dengan apa yang dispesifikasikan. (d) Durability (daya tahan), menunjukkan usia produk atau daya tahan dari kerusakan. (e) Service ability (kemampuan pelayanan), yaitu kemampuan suatu produk ketika diperbaiki dengan penilaian yaitu kemudahan, kecepatan, dan kompeten tidaknya layanan yang diberikan untuk produk tersebut. (f) Aesthetics (keindahan), menyangkut tampilan sehingga dapat menimbulkan perasaan suka konsumen yang seringkali dapat ditunjukkan melalui desai produk atau kemasan. (g) Perceived quality (kualitas yang dipersepsikan), yaitu menyangkut penilaian konsumen terhadap citra, merek, atau iklan. 
Inovasi produk berkaitan dengan hal baru yang diciptakan sebagai bentuk terobosan terhadap produk, jasa, ide, dan persepsi dari seseorang yang dapat berupa produk-produk yang baru, pengembangan produk-produk baru, perubahan desain, inovasi teknis, hingga pemikiran bisnis baru atau proses yang baru (Kotler \& Keller, 2009; (Zimmerer \& Scarborough, 2008). Inovasi juga merupakan mekanisme yang dijalankan perusahaan untuk beradaptasi dengan lingkungan dinamis demi mempertahankan kelangsungan hidup perusahaan serta menciptakan keunggulan dalam persaingan. Inovasi akan dikatakatan berhasil apabila produk inovatif tersebut mampu memberikan pelayanan yang memuaskan bagi pelanggan sehingga tidak hanya terobosan, inovasi produk juga merupakan solusi dari hasil evaluasi terhadap produk yang lama atau produk sebelumnya. Karakteristik inovasi terdiri atas lima hal yaitu (Setiadi, 2010) : (a) Keunggulan relatif (relative advantage), yaitu bentuk karakteristik inovasi yang memberikan evaluasi keberhasilan potensial dari suatu produk yang baru terhadap produk lama atau produk yang digantikan. (b) Keserasian/kesesuaian (compability), yaitu tingkat konsistensi produk terhadap nilai yang sudah ada atau pengalaman penggunaan produk di masa lalu. (c) Kekompleksan (complexity), yaitu inovasi tidak diterima oleh karena kompleksitas inovasi tersebut sehingga sulit dimengerti dan digunakan. (d) Ketercobaan (triability), yaitu percobaan atau uji coba yang dilakukan untuk melihat apakah inovasi tersebut mampu menunjukkan keunggulannya sehingga mempercepat proses pengadopsian inovasi tersebut. (e) Keterlihatan (observability), yaitu tingkatan hasil penggunaan atau adopsi inovasi setelah inovasi tersebut sering dilihat yang kemudian dapat menyebabkan semakin mudahnya proses adopsi inovasi oleh orang atau sekelompok orang.

Kepuasan pelanggan merupakan keberhasilan suatu usaha karena dapat meningkatkan tingkat profitabilitas dan memperluas pangsa pasar yang mana perasaan puas ini akan menimbulkan rencana untuk pembelian ulang dan sebaliknya apabila pelanggan merasa tidak puas maka pelanggan akan merespon dengan tindakan mendiamkan saja atau dapat juga melakukan komplain atas keluhan yang dirasakan (Surbakti \& Widyarini, 2010; Consuegra et al., 2007; Hidayat et al., 2012). Kepuasan pelanggan berhubungan dengan kesesuaian kinerja produk terhadap harapan yang diekspektasikan oleh pelanggan tersebut setelah hasil dari pengalaman pembelian dan konsumsi yang diukur melalui evaluasi terhadap layanan dan produk sehingga jika dilihat dari sudut pandang manajerial, mempertahankan kepuasan pelanggan dan meningkatkannya merupakan hal yang sangat penting (Yuliastina \& Made Jatra, 2014; Adhiyanto, 2012); Chien-Hsiung, et al., (2011); Suprapti, (2010). Indikator kepuasan yang dapat digunakan sebagai acuan yaitu kepuasan secara keseluruhan, konfirmasi harapan, serta perasaan senang yang timbul setelah penggunaan produk (Nurlina, 2013). Secara bersamaan, konsep berikut juga dapat digunakan untuk mengukur kepuasan pelanggan, yaitu (Husein, 2003): (a) Kepuasan secara keseluruhan, yaitu melalui kinerja produk secara umum. (b) Dimensi kepuasan pelanggan, yaitu dapat dilakukan melalui empat langkah antara lain, melakukan identifikasi terhadap dimensi-dimensi kunci kepuasan pelanggan; menumbuhkan atau menarik kesediaan pelanggan untuk melakukan penilaian terhadap pelayanan perusahaan berdasarkan item yang spesifik; meminta pelanggan melakukan penilaian terhadap produk berdasarkan 
item spesifik yang sama; serta meminta/mengarahkan pelanggan untuk memberikan dimensi-dimensi lainnya yang berhubungan dengan penilaian kepuasan secara keseluruhan. (a) Konfirmasi harapan, yaitu pengukuran kepuasan secara tidak langsung yang dilakukan dengan menyimpulkan kesesuaian atau ketidakpuasan antara harapan pelanggan dengan kinerja aktual suatu produk. (b) Minat pembelian ulang (repurchase), yaitu kepuasan yang diukur berdasarkan kesediaan/kemauan pelanggan untuk melakukan pembelian kembali atas pelayanan sama yang telah dikonsumsi sebelumnya. (c) Kesediaan pelanggan untuk merekomendasikan, yaitu kepuasan yang diukur ketika pelanggan melakukan marketing secara tidak langsung kepada seseorang atau sekelompok orang untuk melakukan pembelian terhadap produk yang ia gunakan. (d) Ketidakpuasan pelanggan, yaitu mengetahui ketidakpuasan melalui komplain, penggunaan/claim garansi, defections, serta word of mouth negatif. Loyalitas merupakan sikap menyenangi suatu produk yang kemudian dapat menciptakan komitmen mendalam untuk melakukan pembelian kembali secara konsisten meskipun terdapat pengaruh situasi atau usaha pemasaran berpotensi yang dapat menyebabkan pelanggan tidak loyal (Kotler \& Keller, 2009); (Sutisna, 2001). Loyalitas pelanggan dapat timbul oleh karena pelanggan puas terhadap kualitas produk maupun kualitas pelayanan dari produk yang kemudian pelanggan cenderung setia untuk waktu yang lama dan akan melakukan pembelian kembali ketika perusahaan memproduksi produk baru ataupun memperbaiki produk lamanya (Sutisna, 2001; Kotler \& Keller, 2009). Pelanggan loyal tidak hanya berhenti pada penggunaan produk yang sama, melainkan akan melanjutkan tindakan yaitu dengan cara melakukan rekomendasi terhadap produk yang telah dikonsumsinya kepada orang lain (Yu \& Alison, 2000). Berikut ini indikator-indikator yang digunakan untuk mengukur loyalitas antara lain (Sunarto, 2006): (a) Komitmen, yaitu perilaku konsumen yang memutuskan untuk tetap menggunakan produk atau merek yang sama dan tidak memiliki keinginan untuk menggunakan produk dengan merek lainnya di masa mendatang. (b) Pembelian ulang, yaitu konsumen melakukan pembelian produk yang sama secara berulang. (c) Rekomendasi, yaitu konsumen menyebarkan pengalamannya mengenai penggunaan suatu produk kepada orang lain agar orang tersebut bersedia untuk mengkonsumsi produk sama dengan yang digunakannya.Hipotesis pertama yaitu kualitas layanan memiliki pengaruh positif dan signifikan terhadap kepuasan konsumen merupakan hipotesis yang sejalan dengan hasil penelitian Putro, dkk., (2014) terkait kualitas layanan pada restoran Happy Garden yang memiliki pengaruh positif dan signifikan terhadap kepuasan konsumen. Penelitian lain yaitu Aditya \& Ni Made Wulandari Kusuma Dewi, (2017) dan Putra \& Sulistyawati, (2018) menemukan kualitas pelayanan berpengaruh positif dan signifikan terhadap kepuasan pelanggan. Hal ini berarti jika layanan ditingkatkan maka kepuasan konsumen juga meningkat.

$\mathrm{H}_{1}$ : Kualitas layanan memiliki pengaruh positif dan signifikan terhadap kepuasan pelanggan.

Hipotesis kedua yaitu kualitas produk memiliki pengaruh positif dan signifikan terhadap kepuasan konsumen merupakan hipotesis yang sejalan dengan hasil penelitian Putro dkk. (2014) yang menyimpulkan bahwa kualitas produk pada restoran Happy Garden memiliki pengaruh positif dan signifikan terhadap kepuasan 
konsumen restoran Happy Garden. Penelitian lain yang sejalan dengan penelitian Putro adalah penelitian Andreas, (2016) serta penelitian Wijaya \& Nurcaya, (2017) yang menghasilkan kesimpulan bahwa kualitas produk berpengaruh signifikan terhadap kepuasan pelanggan. Hal ini berarti jika kualitas produk meningkat maka kepuasan konsumen juga akan meningkat.

$\mathrm{H}_{2}$ : Kualitas produk memiliki pengaruh positif dan signifikan terhadap kepuasan pelanggan.

Hipotesis ketiga yaitu inovasi produk memiliki pengaruh positif dan signifikan terhadap kepuasan konsumen merupakan hipotesis yang sejalan dengan hasil penelitian Antanegoro \& Fauzi Sanusi, (2017) yang menyimpulkan bahwa inovasi produk berpengaruh positif dan signifikan terhadap kepuasan konsumen. Sukarmen dkk. (2013) dalam penelitiannya menemukan bahwa inovasi produk dapat meningkatkan kepuasan konsumen. Penelitian lainnya yaitu Natalia, (2009) menghasilkan adanya pengaruh positif signifikan terhadap kepuasan konsumen sehingga jika inovasi produk semakin baik maka semakin meningkat kepuasan konsumen.

$\mathrm{H}_{3}$ : Inovasi produk memiliki pengaruh positif dan signifikan terhadap kepuasan pelanggan.

Hipotesis keempat yaitu kepuasan konsumen memiliki pengaruh yang positif dan signifikan terhadap loyalitas konsumen merupakan hipotesis yang sejalan dengan hasil penelitian Prabowo, (2008) mengemukakan bahwa kepuasan pelanggan berpengaruh positif terhadap loyalitas PT. Astra Surabaya. Penelitian lainnya yaitu oleh Putro dkk. (2014) yang menyimpulkan bahwa kepuasan pelanggan pada restoran Happy Garden memiliki pengaruh yang positif dan signifikan terhadap loyalitas konsumen. Penelitian Utami, dan Khasanah, (2016) juga menemukan kepuasan pelanggan memiliki pengaruh positif dan signifikan terhadap loyalitas pelanggan pengguna Iphone merek Apple. Hal ini berarti loyalitas pelanggan akan tumbuh jikaa pelanggan merasa puas dan sikap positif terhadap produk akan menumbuhkan minat untuk melakukan pembelian ulang.

$\mathrm{H}_{4}$ : Kepuasan pelanggan memiliki pengaruh yang positif dan signifikan terhadap loyalitas pelanggan.

Penarikan keempat hipotesis tersebut dapat dijelaskan dalam model kerangka konseptual seperti yang digambarkan pada Gambar 1.

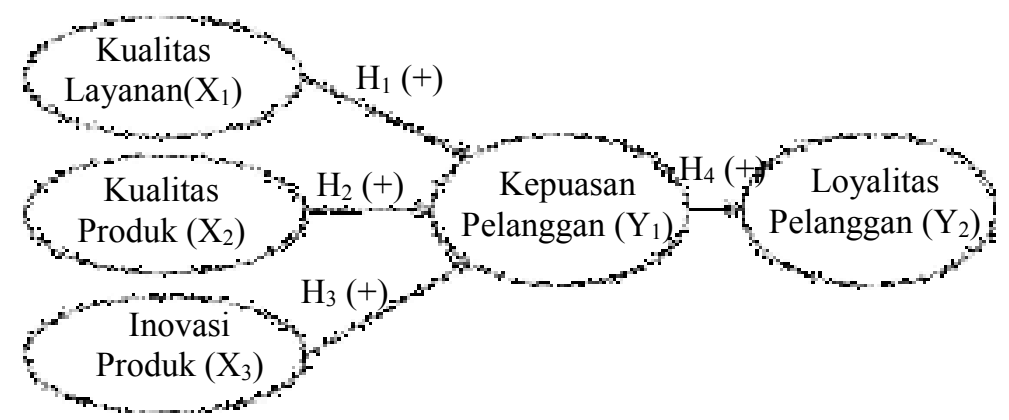

Gambar 1. Model Kerangka Konseptual 


\section{METODE PENELITIAN}

Penelitian ini merupakan penelitian yang bersifat asosiatif bertujuan untuk mengetahui/memperoleh hubungan sebab akibat dari variabel yang mempengaruhi (variabel bebas) terhadap variabel yang sudah dipengaruhi. Sebelum penelitian ini dilanjutkan, pra-survei telah dilakukan terlebih dahulu untuk menemukan perusahaan yang tepat untuk melakukan penelitian hingga ditemukan sebuah perusahaan yang masih memiliki pelanggan yang tidak loyal sehingga penelitian ini dapat dilakukan sekaligus untuk melakukan evaluasi terhadap perusahaan. Berdasarkan hasil pra-survei, rata-rata pelanggan telah merasa puas dan loyal terhadap produk yang diberikan CV. Bintang Harapan Kurnia.

Tabel 1.

\begin{tabular}{|c|c|c|c|c|c|c|c|}
\hline \multicolumn{8}{|c|}{ Hasil Pra-survei Loyalitas Pelanggan } \\
\hline No & Daftar Pertanyaan & STS & TS & CS & $\mathbf{S}$ & SS & Jumlah \\
\hline 1 & $\begin{array}{l}\text { Saya akan tetap menggunakan produk CV } \\
\text { Bintang Harapan Kurnia }\end{array}$ & 0 & 0 & 1 & 7 & 2 & 10 \\
\hline 2 & $\begin{array}{l}\text { Saya akan melakukan pembelian kembali } \\
\text { produk CV Bintang Harapan Kurnia, jika } \\
\text { mengeluarkan varian baru }\end{array}$ & 0 & 0 & 2 & 5 & 3 & 10 \\
\hline 3 & $\begin{array}{l}\text { Saya akan merekomendasikan produk CV } \\
\text { Bintang Harapan Kurnia kepada orang lain }\end{array}$ & 0 & 0 & 0 & 6 & 4 & 10 \\
\hline & Jumlah & 0 & 0 & 3 & 18 & 9 & \\
\hline
\end{tabular}

Keterangan:

STS : Sangat Tidak Setuju, skor 1

TS : Tidak Setuju, skor 2

CS : Cukup Setuju, skor 3

S : Setuju, skor 4

SS : Sangat Setuju, skor 5

Berdasarkan Tabel 1. responden cenderung berada pada skor cukup setuju hingga sangat setuju, hal ini mengindikasikan bahwa masih adanya pelanggan yang kurang loyal terhadap produk CV Bintang Harapan dan perlu diketahui penyebabnya berdasarkan indikator-indikator yang sesuai.

Lokasi yang dipilih adalah Kota Denpasar dengan alasan bahwa pusat kota memiliki pertumbuhan sektor ekonomi masyarakat yang sangat cepat serta memiliki jumlah penduduk yang padat. Selain itu secara teknis, kota Denpasar memenuhi kategori dalam menyelenggarakan penelitian yang relevan yaitu oleh karena banyaknya pengusaha konveksi yang cocok dengan penelitian. Sedangkan obyek yang diteliti adalah perilaku konsumen yang pernah menggunakan atau melakukan pembelian produk pada CV. Bintang Harapan Kurnia yang meliputi kepuasan konsumen serta loyalitas dalam menggunakan produk perusahaan yang kemudian akan dihubungkan dengan variabel kualitas layanan, kualitas produk, dan inovasi produk.

Populasi dalam penelitian ini adalah pelanggan yang sudah pernah membeli atau menggunakan produk dari CV. Bintang Harapan Kurnia dan berdomisili di Kota Denpasar yang tidak diketahui jumlah pasti populasinya (infinite). Metode 
penentuan sampel yang digunakan yaitu non probability sampling dengan teknik purposive sampling yang merupakan teknik pengambilan sampel yang tidak memberi peluang atau kesempatan yang sama bagi setiap unsur atau anggota populasi untuk dipilih menjadi sampel dengan pertimbangan tertentu (Rahyuda \& Atmaja, (2017). Kriteria penentuan sampel yang digunakan dalam penelitian ini adalah sebagai berikut. (a) Kriteria pertama yaitu responden minimal sedang menempuh atau telah menyelesaikan pendidikan dijenjang SMA/SMK sederajat atau telah berusia minimal 17 tahun. Kriteria ini gunakan dengan pertimbangan bahwa seseorang yang sedang atau telah menyelesaikan pendidikan pada jenjang tersebut sudah dapat memahami isi kuesioner serta dapat mengisi kuisioner penelitian. (b) Pernah melakukan pembelian produk di CV. Bintang Harapan Kurnia dalam kurun waktu 6 bulan terakhir. (c) Berdomisili di Kota Denpasar.

Penentuan sampel dilakukan dengan mempertimbangkan bahwa penelitian ini dianalisis dengan multivariate, sehingga jumlah anggota sampel minimal berjumlah 5-10 kali dari jumlah total indikator yang akan diteliti (Sugiyono, 2016). Oleh karena penelitian menggunakan 18 indikator, sehingga rentang jumlah anggota sampel adalah 90-180 orang, dan penelitian ini menggunakan 100 anggota sampel.

Kuesioner merupakan metode pengumpulan data yang digunakan dalam penelitian ini yaitu dengan cara menyebarkan daftar pertanyaan secara tertulis yang berkaitan dengan variabel. Kuesioner yang digunakan terdiri atas pernyataan terbuka dan tertutup. Pertanyaan terbuka merupakan identitas responden sedangkan pertanyaan tertutup meliputi pertanyaan yang berhubungan dengan indikator dalam penelitian dengan jawaban yang harus dipilih salah satu oleh responden. Skala yang digunakan adalah skala likert dengan tabel penentuan skor ditunjukkan pada Tabel 2 (Sugiyono, 2016).

Tabel 2.

Penentuan Skor Kuesioner

\begin{tabular}{ccc}
\hline Jawaban & Kode & Skor \\
\hline Sangat Setuju & SS & 5 \\
Setuju & ST & 4 \\
Cukup Setuju & CS & 3 \\
Tidak Setuju & TS & 2 \\
Sangat Tidak Setuju & STS & 1 \\
\hline
\end{tabular}

Sumber: Sugiyono, 2016

Data yang diperoleh dianalisis dengan menggunakan statistik deskriptif dan statistik inferensial. Analisis statistik deskriptif adalah perhitungan statistik, baik menggambarkan karakteristik sampel maupun hubungan antarvariabel dalam sampel. Statistik deskriptif hanya meringkas serangkaian pengamatan sampel. Statistik deskriptif merupakan media untuk mendeskripsikan data dalam bentuk dikelola (Rahyuda \& Atmaja, 2017).

Analisis statistik inferensial adalah perhitungan statistik yang membantu periset untuk mengambil simpulan tentang populasi. Simpulan ditarik berdasarkan informasi yang diperoleh dari pengamatan (sampel) dari populasi tersebut (Rahyuda \& Atmaja, 2017). Statistik inferensial adalah tubuh penghitungan statistik 
yang relevan untuk membuat simpulan dari temuan berdasarkan observasi sampel atas populasi yang lebih besar. Penelitian ini menggunakan teknik analisis inferensial yaitu PLS.

PLS merupakan salah satu metode analisa yang bisa diterapkan untuk seluruh skala data, tidak memerlukan asumsi yang banyak, ukuran sampelnya tidak diharuskan besar, dapat dipergunakan untuk pembuktian teori, dan juga dapat digunakan untuk mengembangkan hubungan yang belum mempunyai landasan teori yang kuat.

\section{HASIL PENELITIAN DAN PEMBAHASAN}

Karakteristik responden merupakan data responden yang dikumpulkan untuk mengetahui profil responden penelitian. Pada Tabel 3, dapat dilihat karyawan berjenis kelamin pria lebih mendominasi yaitu sebesar $67 \%$ dari total sampel yang digunakan. Hal ini menunjukan sebagian besar pengunjung atau pelanggan adalah berjenis kelamin pria. Pada tabel 3 dapat dilihat pula sebagian besar responden berusia 20-30 tahun. Dilihat dari segi pendidikan terakhir, dominan pelanggan dengan pendidikan perguruan tinggi serta dominan berprofesi sebagai mahasiswa karena mahasiswa memiliki waktu luang untuk berbelanja yang lebih banyak dibandingkan dengan profesi/pekerjaan lainnya. Tabel ini menjelaskan karakteristik responden yang terpilih untuk melanjutkan penelitian dengan catatan bahwa hasil yang berbeda mungkin saja diperoleh pada penelitian lainnya oleh karena responden yang terpilih pun bersifat random atau acak. Sehingga kemungkinan hasil yang berbeda juga dapat dipengaruhi oleh jawaban dan persepsi dari individu yang berbeda.

Tabel 3.

Karakteristik Responden

\begin{tabular}{|c|c|c|c|c|}
\hline No & Karakteristik & Klasifikasi & $\begin{array}{c}\text { Jumlah Responden } \\
\text { (orang) }\end{array}$ & $\begin{array}{c}\text { Presentase } \\
\text { Responden (\%) }\end{array}$ \\
\hline \multirow{3}{*}{1} & \multirow{2}{*}{ Jenis Kelamin } & Pria & 67 & 67 \\
\hline & & Wanita & 33 & 33 \\
\hline & \multicolumn{2}{|c|}{ Jumlah } & 100 & 100 \\
\hline \multirow{4}{*}{2} & \multirow{3}{*}{ Usia } & 15 - 19 Tahun & 40 & 40 \\
\hline & & 20 - 30 Tahun & 48 & 48 \\
\hline & & $>30$ Tahun & 12 & 12 \\
\hline & \multicolumn{2}{|c|}{ Jumlah } & 100 & 100 \\
\hline \multirow{3}{*}{3} & \multirow{2}{*}{ Pendidikan } & SMA/SMK & 42 & 42 \\
\hline & & Perguruan Tinggi & 58 & 58 \\
\hline & \multicolumn{2}{|c|}{ Jumlah } & 100 & 100 \\
\hline \multirow{7}{*}{4} & \multirow{7}{*}{$\begin{array}{c}\text { Pekerjaan dan } \\
\text { Status }\end{array}$} & Pegawai & & \\
\hline & & Negeri/ABRI & 4 & 4 \\
\hline & & Pegawai Swasta & 16 & 16 \\
\hline & & Wiraswasta & 13 & 13 \\
\hline & & Pelajar & 24 & 24 \\
\hline & & Mahasiswa & 41 & 41 \\
\hline & & Ibu Rumah Tangga & 2 & 2 \\
\hline \multirow[t]{2}{*}{ Jumlah } & & & 100 & \\
\hline & & & & 100 \\
\hline
\end{tabular}

Sumber: Data diolah, 2018 
Uji validitas bertujuan untuk memeriksa apakah kuesioner sebagai instrumen penelitian sudah tepat digunakan untuk mengukur indikator dalam penelitian. Pernyataan-pernyataan dalam kuesioner dikatakan valid apabila koefisien korelasi $\geq 0,3$.

Tabel 4. menunjukkan seluruh instrumen penelitian yang digunakan untuk mengukur variabel kualitas layanan, kualitas produk, inovasi produk, kepuasan pelanggan dan loyalitas pelanggan. Kualitas layanan memperoleh nilai rata-rata koefisien korelasi untuk kelima indikator sebesar 0,779. Kualitas produk memperoleh nilai rata-rata koefisien korelasi untuk keempat indikator sebesar 0,787. Inovasi produk memperoleh nilai koefisien korelasi rata-rata untuk ketiga indikator sebesar 0,801. Kepuasan pelanggan memperoleh nilai rata-rata koefisien korelasi untuk ketiga indikator sebesar 0,769. Sedangkan loyalitas pelanggan memperoleh nilai rata-rata koefisien korelasi untuk ketiga indikator sebesar 0,808. Dengan demikian kelima variabel memiliki nilai koefisien korelasi dengan skor total seluruh item pernyataan lebih besar dari $0,3(>0,3)$. Hal ini menunjukkan bahwa butir-butir pernyataan dalam instrumen penelitian tersebut valid atau layak digunakan sebagai instrumen penelitian.

Tabel 4.

Hasil Uji Validitas

\begin{tabular}{|c|c|c|c|c|}
\hline Variabel & Indikator & Koef. Korelasi & Korelasi Batas & Keterangan \\
\hline Kualitas Layanan & $\mathrm{X}_{1.1}$ & 0,764 & 0,3 & Valid \\
\hline \multirow[t]{4}{*}{$\left(\mathrm{X}_{1}\right)$} & $\mathrm{X}_{1.2}$ & 0,814 & 0,3 & Valid \\
\hline & $\mathrm{X}_{1.3}$ & 0,771 & 0,3 & Valid \\
\hline & $\mathrm{X}_{1.4}$ & 0,760 & 0,3 & Valid \\
\hline & $\mathrm{X}_{1.5}$ & 0,787 & 0,3 & Valid \\
\hline Kualitas Produk & $\mathrm{X}_{2.1}$ & 0,795 & 0,3 & Valid \\
\hline \multirow{3}{*}{$\left(\mathrm{X}_{2}\right)$} & $\mathrm{X}_{2.2}$ & 0,822 & 0,3 & Valid \\
\hline & $\mathrm{X}_{2.3}$ & 0,765 & 0,3 & Valid \\
\hline & $\mathrm{X}_{2.4}$ & 0,767 & 0,3 & Valid \\
\hline Inovasi Produk & $\mathrm{X}_{3.1}$ & 0,813 & 0,3 & Valid \\
\hline \multirow[t]{2}{*}{$\left(\mathrm{X}_{3}\right)$} & $\mathrm{X}_{3.2}$ & 0,797 & 0,3 & Valid \\
\hline & $\mathrm{X}_{3.3}$ & 0,793 & 0,3 & Valid \\
\hline Kepuasan & $Y_{1.1}$ & 0,729 & 0,3 & Valid \\
\hline \multirow[t]{2}{*}{ Pelanggan $\left(\mathrm{Y}_{1}\right)$} & $\mathrm{Y}_{1.2}$ & 0,715 & 0,3 & Valid \\
\hline & $\mathrm{Y}_{1.3}$ & 0,863 & 0,3 & Valid \\
\hline Loyalitas & $\mathrm{Y}_{2.1}$ & 0,850 & 0,3 & Valid \\
\hline \multirow{2}{*}{ Pelanggan $\left(\mathrm{Y}_{2}\right)$} & $\mathrm{Y}_{2.2}$ & 0,730 & 0,3 & Valid \\
\hline & $\mathrm{Y}_{2.3}$ & 0,843 & 0,3 & Valid \\
\hline
\end{tabular}

Uji reliabilitas dilakukan untuk mengetahui konsistensi dari alat ukur yang digunakan sehingga meskipun alat ukur tersebut digunakan kembali maka akan mendapatkan hasil yang sama pula. Data dianggap reliabel apabila Alpha Cronbach $\geq 0,6$. Penjelasan terdapat pada Tabel 5 . 
Tabel 5.

Hasil Uji Reliabilitas

\begin{tabular}{clcc}
\hline No. & \multicolumn{1}{c}{ Variabel } & Cronbach's Alpha & Keterangan \\
\hline 1. & Kualitas Layanan $\left(\mathrm{X}_{1}\right)$ & 0,838 & Reliabel \\
2. & Kualitas Produk $\left(\mathrm{X}_{2}\right)$ & 0,783 & Reliabel \\
3. & Inovasi Produk $\left(\mathrm{X}_{3}\right)$ & 0,714 & Reliabel \\
4. & Kepuasan Pelanggan $\left(\mathrm{Y}_{1}\right)$ & 0,657 & Reliabel \\
5. & Loyalitas Pelanggan $\left(\mathrm{Y}_{2}\right)$ & 0,734 & Reliabel \\
\hline
\end{tabular}

Sumber: Data Diolah, 2018

Hasil uji reliabilitas yang disajikan dalam Tabel 5. menunjukkan nilai cronbach's alpha pada kualitas layanan adalah sebesar 0,838 ; kualitas produk sebesar 0,783; inovasi produk sebesar 0,714 ; kepuasan pelanggan sebesar 0,657 ; serta loyalitas pelanggan sebesar 0,734 . Keseluruhan nilai cronbach's alpha dari masing-masing variabel memiliki nilai koefisien yang lebih besar dari 0,6 $(>0,6)$, sehingga seluruh variabel dapat dinyatakan telah memenuhi syarat reliabilitas atau reliabel.

Outer model merupakan spesifikasi hubungan antara variabel laten dengan indikatornya, atau disebut juga dengan outer relation/measurement model yang mendefinisikan karakteristik konstruk dengan variabel manifes. Langkah penetapan hasil evaluasi dilakukan dengan menemukan convergent validity, discriminant validity dengan menggunakan cross loading, discriminant validity dengan menggunakan akar kuadrat AVE dan korelasi variabel laten, serta mengukur composite reliability.

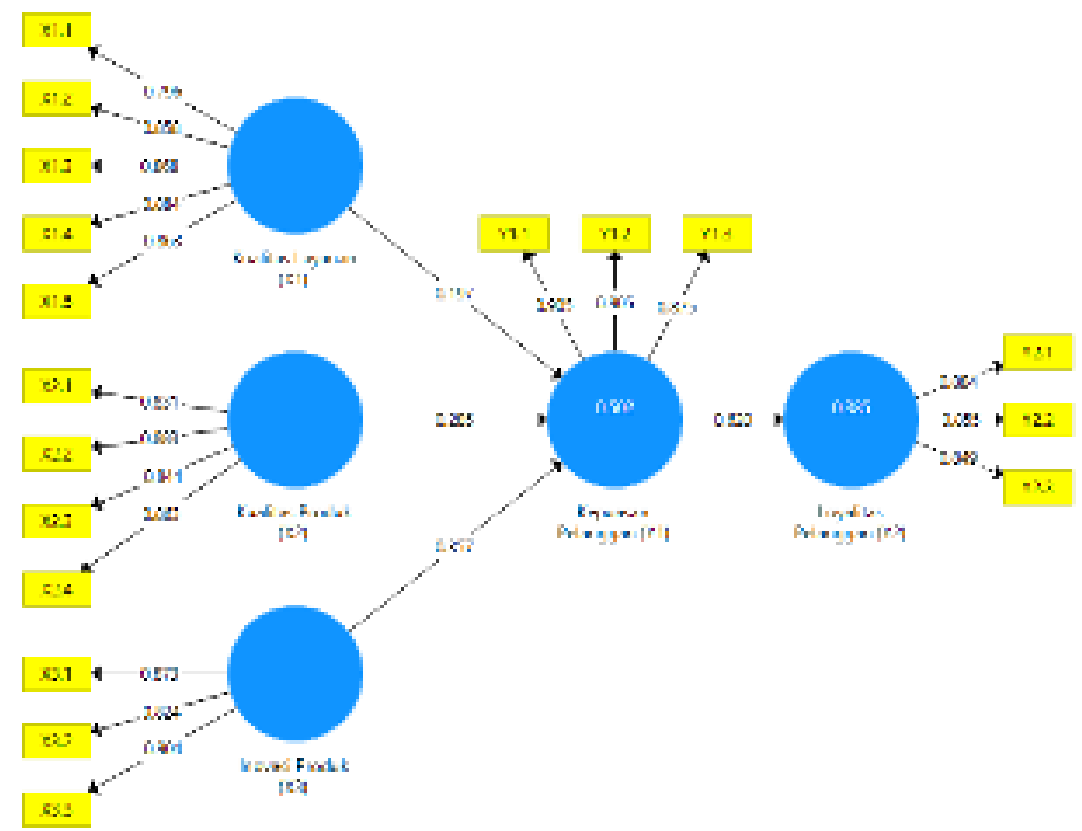

Gambar 2.

Gambar Outer Model

Sumber: Data Diolah, 2018

Convergent validity merupakan korelasi antar skor indikator refleksif dengan skor variabel latennya, yang mana indikator individu dianggap reliabel apabila 
memiliki nilai outer laodings diatas 0,7 . Berdasarkan Tabel 6. dapat dilihat bahwa semua nilai pada uji validitas convergent lebih besar dari 0,7 . Dengan demikian dapat dinyatakan bahwa data dalam penelitian valid.

Discriminant validity merupakan Pengukuran indikator refleksif berdasarkan cross loading dengan variabel latennya. Apabila nilai croos loading setiap indikator dari variabel yang bersangkutan lebih besar dibandingkan dengan cross loading variabel lain, maka indikator tersebut dikatakan valid. Nilai validitas diskriminan lebih besar dari pada 0,5 maka variabel laten tersebut sudah menjadi pembanding yang baik untuk model. Berdasarkan Tabel 7. dapat dilihat bahwa semua nilai cross loading setiap indikator pada masing - masing variabel lebih besar dari 0,5 Dengan demikian dapat dinyatakan bahwa data dalam penelitian valid.

Tabel 6.

Hasil Uji Validitas Convergent Validity

\begin{tabular}{|c|c|c|c|c|c|}
\hline & $\begin{array}{l}\text { Inovasi } \\
\text { Produk (X3) }\end{array}$ & $\begin{array}{l}\text { Kepuasan } \\
\text { Pelanggan (Y1) }\end{array}$ & $\begin{array}{l}\text { Kualitas } \\
\text { Layanan (X1) }\end{array}$ & $\begin{array}{l}\text { Kualitas } \\
\text { Produk (X2) }\end{array}$ & $\begin{array}{l}\text { Loyalitas } \\
\text { Pelanggan } \\
\text { (Y2) }\end{array}$ \\
\hline $\mathrm{X}_{1.1}$ & & & 0.796 & & \\
\hline$X_{1.2}$ & & & 0.858 & & \\
\hline $\mathbf{X}_{1.3}$ & & & 0.868 & & \\
\hline $\mathbf{X}_{1.4}$ & & & 0.884 & & \\
\hline $\mathbf{X}_{1.5}$ & & & 0.863 & & \\
\hline $\mathbf{X}_{2.1}$ & & & & 0.831 & \\
\hline $\mathbf{X}_{2.2}$ & & & & 0.883 & \\
\hline $\mathbf{X}_{2.3}$ & & & & 0.844 & \\
\hline $\mathbf{X}_{2.4}$ & & & & 0.863 & \\
\hline $\mathbf{X}_{3.1}$ & 0.873 & & & & \\
\hline $\mathbf{X}_{3.2}$ & 0.824 & & & & \\
\hline $\mathbf{X}_{\mathbf{3 . 3}}$ & 0.904 & & & & \\
\hline$Y_{1.1}$ & & 0.905 & & & \\
\hline $\mathbf{Y}_{1.2}$ & & 0.905 & & & \\
\hline $\mathbf{Y}_{1.3}$ & & 0.875 & & & \\
\hline $\mathbf{Y}_{2.1}$ & & & & & 0.884 \\
\hline $\mathbf{Y}_{2.2}$ & & & & & 0.855 \\
\hline$Y_{2.3}$ & & & & & 0.849 \\
\hline
\end{tabular}

Model lain untuk menilai discriminate validity adalah membandingkan akar kuadrat dari average variance extracted (AVE) untuk setiap variabel dengan korelasi antar variabel dengan variabel lainnya didalam model. Model memiliki discrimint yang baik apabila kuadrat AVE untuk setiap variabel lebih besar daripada korelasi antar variabel dan variabel lain dalam satu model atau direkomendasikan nilai pengukuran AVE lebih besar dari 0,5. Berdasarkan Tabel 8. dapat dilihat bahwa semua nilai AVE validitas confergent lebih besar dari 0,5 sehingga data dalam penelitian adalah valid. 
Composite reliability yaitu kelompok indikator yang mengukur sebuah variabel yang memiliki reliabilitas komposit baik, variabel dinyatakan reliabel jika nilai composite reliability $\geq 0,6$. Berdasarkan Tabel 9. dapat dilihat bahwa semua nilai Cronbach 's alpha pada masing-masing variabel lebih besar dari 0,6, sehingga dapat dinyatakan bahwa data dalam penelitian reliabel. Sedangkan pada Tabel 10 dapat dilihat bahwa semua nilai Composite reliability pada masing-masing variabel lebih besar dari 0,6, dengan demikian penelitian dapat dinyatakan reliabel.

Tabel 7.

Hasil Uji Validitas Discriminant Cross Loading

\begin{tabular}{|c|c|c|c|c|c|}
\hline & $\begin{array}{l}\text { Inovasi } \\
\text { Produk (X3) }\end{array}$ & $\begin{array}{l}\text { Kepuasan } \\
\text { Pelanggan (Y1) }\end{array}$ & $\begin{array}{l}\text { Kualitas } \\
\text { Layanan (X1) }\end{array}$ & $\begin{array}{l}\text { Kualitas } \\
\text { Produk (X2) }\end{array}$ & $\begin{array}{l}\text { Loyalitas } \\
\text { Pelanggan } \\
\text { (Y2) }\end{array}$ \\
\hline $\mathbf{X}_{1.1}$ & 0.368 & 0.309 & 0.796 & 0.387 & 0.539 \\
\hline$X_{1.2}$ & 0.439 & 0.454 & 0.858 & 0.361 & 0.580 \\
\hline $\mathbf{X}_{1.3}$ & 0.426 & 0.423 & 0.868 & 0.414 & 0.552 \\
\hline $\mathbf{X}_{1.4}$ & 0.421 & 0.459 & 0.884 & 0.446 & 0.610 \\
\hline $\mathbf{X}_{1.5}$ & 0.382 & 0.485 & 0.863 & 0.477 & 0.641 \\
\hline $\mathrm{X}_{2.1}$ & 0.609 & 0.538 & 0.382 & 0.831 & 0.553 \\
\hline $\mathbf{X}_{2.2}$ & 0.603 & 0.534 & 0.433 & 0.883 & 0.607 \\
\hline $\mathbf{X}_{2.3}$ & 0.506 & 0.523 & 0.387 & 0.844 & 0.551 \\
\hline$X_{2.4}$ & 0.487 & 0.499 & 0.475 & 0.863 & 0.550 \\
\hline $\mathbf{X}_{3.1}$ & 0.873 & 0.591 & 0.393 & 0.617 & 0.609 \\
\hline $\mathbf{X}_{3.2}$ & 0.824 & 0.494 & 0.427 & 0.490 & 0.482 \\
\hline $\mathbf{X}_{3.3}$ & 0.904 & 0.562 & 0.426 & 0.564 & 0.528 \\
\hline$Y_{1.1}$ & 0.550 & 0.905 & 0.428 & 0.582 & 0.555 \\
\hline$Y_{1.2}$ & 0.618 & 0.905 & 0.459 & 0.543 & 0.555 \\
\hline $\mathbf{Y}_{1.3}$ & 0.537 & 0.875 & 0.475 & 0.519 & 0.556 \\
\hline $\mathbf{Y}_{2.1}$ & 0.436 & 0.532 & 0.615 & 0.503 & 0.884 \\
\hline $\mathbf{Y}_{2.2}$ & 0.548 & 0.554 & 0.602 & 0.572 & 0.855 \\
\hline$Y_{2.3}$ & 0.638 & 0.517 & 0.558 & 0.637 & 0.849 \\
\hline
\end{tabular}

Sumber: Data Diolah, 2018

Tabel 8.

Hasil Uji Validitas Convergent AVE

\begin{tabular}{lr}
\hline & Rata-rata Varians Diekstrak (AVE) \\
\hline Inovasi Produk (X3) & 0.752 \\
Kepuasan Pelanggan (Y1) & 0.801 \\
Kualitas Layanan (X1) & 0.730 \\
Kualitas Produk (X2) & 0.732 \\
Loyalitas Pelanggan (Y2) & 0.744 \\
\hline
\end{tabular}

Sumber: Data Diolah, 2018 
Tabel 9.

Hasil Uji Reliabilitas Cronbach's Alpha

\begin{tabular}{lr}
\hline & Cronbach's \\
\hline Alpha \\
\hline Kevasi Produk (X3) & 0.835 \\
Kualitas Layanan (X1) & 0.876 \\
Kualitas Produk (X2) & 0.908 \\
Loyalitas Pelanggan (Y2) & 0.878 \\
\hline Sumber: Data Diolah, 2018 & 0.828 \\
\hline
\end{tabular}

Tabel 10.

Hasil Uji Reliabilitas Composite Reliability

\begin{tabular}{|c|c|}
\hline & Reliabilitas Komposit \\
\hline Inovasi Produk (X3) & 0.901 \\
\hline Kepuasan Pelanggan (Y1) & 0.924 \\
\hline Kualitas Layanan (X1) & 0.931 \\
\hline Kualitas Produk (X2) & 0.916 \\
\hline Loyalitas Pelanggan (Y2) & 0.897 \\
\hline
\end{tabular}

Pengujian inner model dilakukan dengan melihat nilai $R$-square yang merupakan uji goodness of fit model.

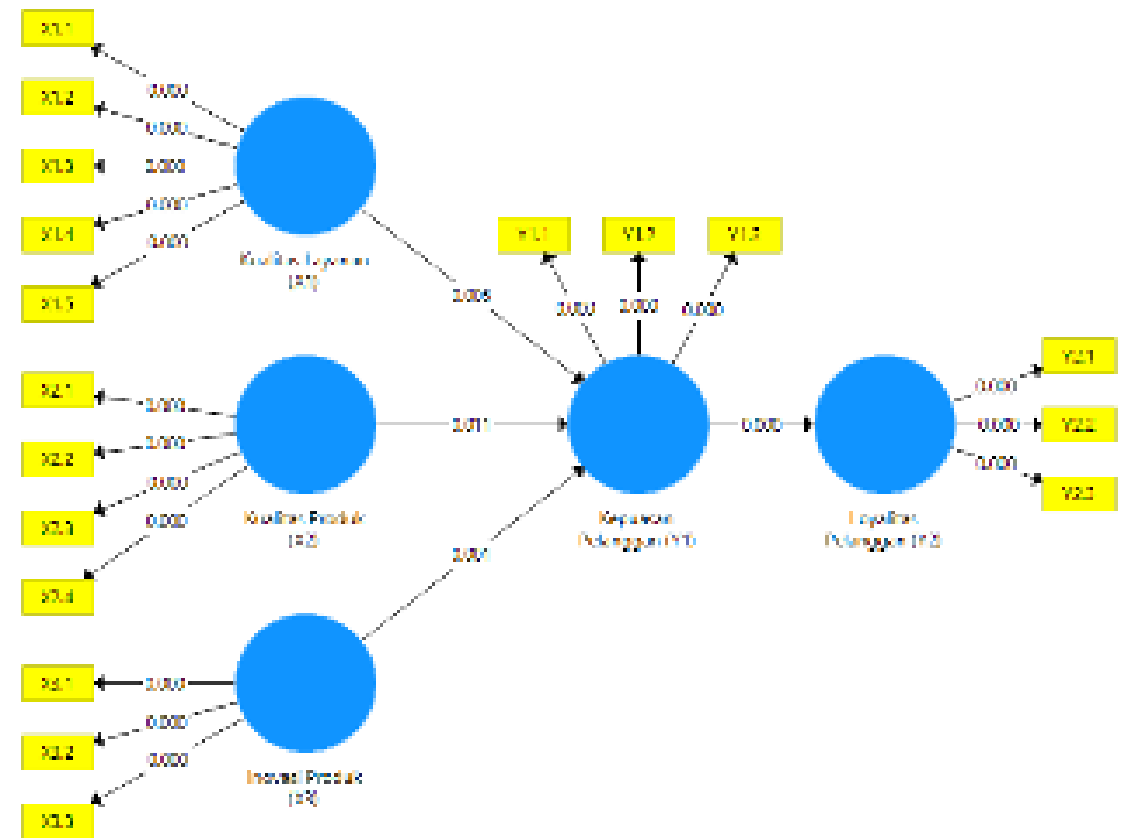

Gambar 3.

Sumber: Data Diolah, 2018

Hasil Inner Model 
Apabila nilai $R$-square $>0$ (nol), model berarti mempunyai nilai predictive relvance, sedangkan nilai $R$-square $<0$ (nol) memiliki arti bahwa model kurang predictive relevance. Namun, jika hasil perhitungan memperlihatkan nilai $R$-square $>0$ (nol), maka model layak dikatakan memiliki nilai prediktif yang relevan.

Tabel 11. Hasil Uji R-Square

\begin{tabular}{lrr}
\hline & R Square & Adjusted R Square \\
\hline Kepuasan Pelanggan (Y1) & 0.502 & 0.486 \\
Loyalitas Pelanggan (Y2) & 0.385 & 0.378 \\
\hline Sumber: Data Diolah, 2018 & &
\end{tabular}

Berdasarkan tabel di atas diperoleh nilai R-square untuk variabel kualitas layanan, kualitas produk dan inovasi produk terhadap kepuasan pelanggan sebesar 0,502 yang menunjukkan memiliki besar pengaruh $0,502 \times 100 \%=50,2 \%$. Nilai R-square untuk variabel kualitas layanan, kualitas produk dan inovasi produkterhadap loyalitas pelanggan sebesar 0,385 yang menunjukkan memiliki besar pengaruh $0,385 \times 100 \%=38,5 \%$.

Pengujian hipotesis dilakukan dengan resampling bootstrap. Uji statistik yang digunakan adalah statistik t. Apabila diperoleh nilai t-statistik $>1,985$, maka dapat disimpulkan hasil tersebut signifikan, namun sebaliknya jika nilai t-statistik $<1,985$ maka hasil penelitian tersebut tidak signifikan.

Tabel 12.

Uji Pengaruh Langsung

\begin{tabular}{|c|c|c|c|c|c|}
\hline & $\begin{array}{l}\text { Sampel } \\
\text { Asli } \\
\text { (O) }\end{array}$ & $\begin{array}{l}\text { Sample } \\
\text { Mean (M) }\end{array}$ & $\begin{array}{l}\text { Standar } \\
\text { Deviasi } \\
\text { (STDEV }\end{array}$ & $\begin{array}{l}\text { T Statistik } \\
(\mid \text { O/STDEV } \mid)\end{array}$ & $\begin{array}{l}\mathbf{P} \\
\text { Value } \\
\mathbf{s}\end{array}$ \\
\hline $\begin{array}{l}\text { Inovasi Produk (X3) -> } \\
\text { Kepuasan Pelanggan (Y1) }\end{array}$ & 0.357 & 0.350 & 0.106 & 3.369 & 0.001 \\
\hline $\begin{array}{l}\text { Kepuasan Pelanggan (Y1) -> } \\
\text { Loyalitas Pelanggan (Y2) }\end{array}$ & 0.620 & 0.623 & 0.075 & 8.268 & 0.000 \\
\hline $\begin{array}{l}\text { Kualitas Layanan (X1) -> } \\
\text { Kepuasan Pelanggan (Y1) }\end{array}$ & 0.197 & 0.207 & 0.070 & 2.799 & 0.005 \\
\hline $\begin{array}{l}\text { Kualitas Produk (X2) -> } \\
\text { Kepuasan Pelanggan (Y1) }\end{array}$ & 0.285 & 0.283 & 0.112 & 2.538 & 0.011 \\
\hline
\end{tabular}

Berdasarkan tabel di atas diperoleh nilai $p$-value dan t statistics untuk masingmasing variabel yang dijelaskan sebagai berikut. (a) Nilai $p$-value variabel Inovasi Produk terhadap Kepuasan pelanggan sebesar 0,001 yang dibandingkan dengan signifikan sebesar 0,05 . Karena nilai $p$-value $<$ signifikan $(0,001<0,05)$ dengan nilai beta sebesar positif 0,357 dan nilai t statistics sebesar 3,369 yang dibandingkan dengan t-tabel dengan signifikan 0,05 dan derajat kebebasan $\mathrm{N}-\mathrm{k}=100-5=95$ sebesar 1,985. Karena nilai t-statistics $>$ t-value $(3,369>1,985)$ maka dapat dikatakan bahwa Inovasi produk memiliki pengaruh positif dan signifikan terhadap Kepuasan Pelanggan. (b) Nilai p-value variabel kepuasan pelanggan terhadap 
loyalitas pelanggansebesar 0,000 yang dibandingkan dengan signifikan sebesar 0,05 . Karena nilai $p$-value $<$ signifikan $(0,000<0,05)$ dengan nilai beta sebesar positif 0,620 dan nilai t statistics sebesar 8,268 yang dibandingkan dengan t-tabel dengan signifikan 0,05 dan derajat kebebasan $\mathrm{N}-\mathrm{k}=100-5=95$ sebesar 1,985. Karena nilai t-statistics $>$ t-value $(8,268>1,985)$ maka dapat dikatakan bahwa kepuasan pelanggan memiliki pengaruh positif dan signifikan terhadap loyalitas pelanggan. (c) Nilai $p$-value variabel kualitas layanan terhadap kepuasan pelanggan sebesar 0,005 yang dibandingkan dengan signifikan sebesar 0,05 . Karena nilai $p$ value $<$ signifikan $(0,005<0,05)$ dengan nilai beta sebesar positif 0,197 dan nilai $\mathrm{t}$ statistics sebesar 2,799 yang dibandingkan dengan t-tabel dengan signifikan 0,05 dan derajat kebebasan $\mathrm{N}-\mathrm{k}=100-5=95$ sebesar 1,985. Karena nilai t-statistics $>$ t-value $(2,799>1,985)$ maka dapat dikatakan bahwa kualitas layanan memiliki pengaruh positif dan signifikan terhadap Kepuasan pelanggan. (d) Nilai $p$-value variabel kualitas produk terhadap kepuasanpelanggan sebesar 0,011 yang dibandingkan dengan signifikan sebesar 0,05 . Karena nilai $p$-value $<$ signifikan $(0,011<0,05)$ dengan nilai beta sebesar positif 0,285 dan nilai $t$ statistics sebesar 2,538 yang dibandingkan dengan t-tabel dengan signifikan 0,05 dan derajat kebebasan $\mathrm{N}-\mathrm{k}=100-5=95$ sebesar 1,985. Karena nilai t-statistics $>\mathrm{t}$-value $(2,538>1,985)$ maka dapat dikatakan bahwa kualitas produk memiliki pengaruh positif dan signifikan terhadap Kepuasan pelanggan.

Hasil estimasi struktural seperti disajikan pada Tabel 12 menunjukkan bahwa pengujian terhadap hipotesis pertama menunjukkan signifikasi hubungan antara kualitas layanan dengan kepuasan pelanggan dengan t-statistik sebesar 2.799 ( $>1,985$ ). Nilai koefisien jalur sebesar 0.197 menunjukkan bahwa arah hubungan antara kualitas layanan dengan kepuasan pelanggan adalah positif, sehingga hipotesis $\mathrm{H}_{1}$ dalam penelitian ini yang menyatakan bahwa kualitas layanan berpengaruh positif dan signifikan terhadap kepuasan pelanggan dapat diterima. Hasil ini menjelaskan bahwa semakin baik kualitas layanan yang dirasakan oleh pelanggan, semakin meningkatkan kepuasan pelanggan akan produk CV Bintang Harapan Kurnia di Kota Denpasar.

Hasil ini sejalan dengan penelitian terdahulu yang pernah dilakukan oleh Putro dkk. (2014), Aditya \& Kusuma Dewi, (2017), Putra \& Sulistyawati, (2018) menyatakan bahwa kualitas pelayanan berpengaruh positif dan signifikan terhadap kepuasan pelanggan.

Hasil estimasi structural seperti disajikan pada Tabel 12. menunjukkan bahwa pengujian terhadap hipotesis kedua menunjukkan signifikasi hubungan antara kualitas produk dengan kepuasan pelanggan dengan t-statistik sebesar 2,538 ( $>1,985)$. Nilai koefisien jalur sebesar 0,285 menunjukkan bahwa arah hubungan antara kualitas produk dengan kepuasan pelanggan adalah positif, sehingga hipotesis $\mathrm{H} 2$ dalam penelitian ini yang menyatakan bahwa kualitas produk berpengaruh positif dan signifikan terhadap kepuasan pelanggan dapat diterima. Hasil ini menjelaskan bahwa semakin baik kualitas produk yang dirasakan pelanggan CV Bintang Harapan Kurnia di Kota Denpasar akan meningkatkan kepuasan pelanggan akan produk CV Bintang Harapan Kurnia. 
Hal ini sejalan dengan penelitian terdahulu yang pernah dilakukan oleh Putro, dkk., (2014), Andreas, (2016), Surya et al., (2017) dikatakan bahwa kualitas produk berpengaruh positif signifikan terhadap kepuasan pelanggan.

Hasil estimasi structural seperti disajikan pada Tabel 12 menunjukkan bahwa pengujian terhadap hipotesis ketiga menunjukkan signifikasi hubungan antara inovasi produk dengan kepuasan pelanggan dengan t-statistik sebesar 3,369 ( $>1,985$ ). Nilai koefisien jalur sebesar 0,357 menunjukkan bahwa arah hubungan antara inovasi produk dengan kepuasan pelanggan adalah positif, sehingga hipotesis $\mathrm{H} 3$ dalam penelitian ini yang menyatakan bahwa inovasi produk berpengaruh positif dan signifikan terhadap kepuasan pelanggan dapat diterima. Hasil ini menjelaskan bahwa semakin baik inovasi produk yang dirasakan pelanggan CV Bintang Harapan Kurnia di Kota Denpasar akan meningkatkan kepuasan pelanggan akan produk CV Bintang Harapan Kurnia.

Hal ini sejalan dengan penelitian terdahulu yang pernah dilakukan oleh Antanegoro et al. (2017), Sukarmen et al. (2013) bahwa inovasi produk berpengaruh positif dan signifikan terhadap kepuasan konsumen.

Hasil estimasi structural seperti disajikan pada Tabel 12. menunjukkan bahwa pengujian terhadap hipotesis keempat menunjukkan signifikasi hubungan antara kepuasan pelanggan dengan loyalitas pelanggan dengan t-statistik sebesar 8,268 ( $>1,985)$. Nilai koefisien jalur sebesar 0,620 menunjukkan bahwa arah hubungan antara kepuasan pelanggan dengan loyalitas pelanggan adalah positif, sehingga hipotesis $\mathrm{H} 4$ dalam penelitian ini yang menyatakan bahwa kepuasan pelanggan berpengaruh positif dan signifikan terhadap loyalitas pelanggan dapat diterima. Hasil ini menjelaskan bahwa semakin puas pelanggan CV Bintang Harapan kurnia akan meningkatkan loyalitas pelanggan akan produk CV Bintang Harapan Kurnia.

Hal ini sejalan dengan penelitian terdahulu yang pernah dilakukan oleh Penelitian oleh Prabowo (2008), Putro dkk. (2014), Utami et al. (2016) bahwa kepuasan pelanggan berpengaurh positif signifikan terhadap loyalitas pelanggan.

Berdasarkan hasil penelitian yang dilakukan menunjukkan bahwa penelitian ini telah mampu mengkonfirmasi beberapa peelitian terdahulu, sekaligus memperkuat penelitian terdahulu . Penelitian ini juga memiliki implikasi untuk civitas akademika guna memperkaya penelitian-penelitian baru mengenai variabelvariabel yang diteliti dalam penelitian.

Berdasarkan hasil penelitian ini diharapkan digunakan sebagai masukan bagi produsen CV Bintang Harapan Kurnia, sehingga dapat meningkatkan loyalitas pelanggan dengan memperhatikan kepuasan pelanggan sebagai fokus utamanya. Sebab, dari hasil yang diperoleh, kepuasan pelanggan selain secara langsung dapat mempengaruhi secara positif terhadap terciptanya loyalitas pelanggan, bisa dikatakan pula sebagai variabel yang dapat mempengaruhi antara kualitas pelayanan, kualitas produk, dan inovasi produk terhadap loyalitas pelanggan. Sesuai dengan hasil penelitian ini, indikator yang masih dapat ditingkatkan kembali oleh produsen adalah menambahkan kenyamanan berada di gerai, produk yang memiliki daya tahan kuat, dan selalu meningkatkan kualitas produknya. 


\section{SIMPULAN}

Berdasarkan hasil analisis penelitian dan hasil pembahasan pada bab sebelumnya maka simpulan dari penelitian ini adalah sebagai berikut:

Kualitas layanan berpengaruh positif dan signifikan terhadap kepuasan pelanggan. Hal ini berarti apabila jika kualitas layanan semakin meningkat maka kepuasan pelanggan semakin meningkat pula. Kualitas produk berpengaruh positif dan signifikan terhadap kepuasan pelanggan. Hal ini berarti apabila jika kualitas produk semakin meningkat maka kepuasan pelanggan semakin meningkat pula. Inovasi Produk berpengaruh positif dan signifikan terhadap kepuasan pelanggan atau dapat diartikan apabila inovasi produk semakin meningkat maka kepuasan pelanggan semakin meningkat pula.

Kepuasan pelanggan berpengaruh positif dan signifikan terhadap loyalitas pelanggan. Hal ini berarti apabila jika kepuasan pelanggan semakin meningkat maka loyalitas pelanggan semakin meningkat pula.Berdasarkan hasil penelitian maka penulis memberikan saran yang diharapkan dapat membantu produsen dan manajer CV Bintang Harapan Kurnia di Kota Denpasar serta para peneliti selanjutnya, berdasarkan dari penelitian yang telah dilakukan, menunjukkan bahwa kepuasan pelanggan memiliki pengaruh yang sangat tinggi terhadap terciptanya loyalitas pelanggan. Maka dari itu bagi CV Bintang Harapan Kurnia, diharapkan dapat selalu berupaya untuk meningkatkan kepuasan pelanggan, dengan memperhatikan kepuasan pelanggan terhadap kualitas produk yang dirasakan oleh pelanggan selama menggunakan produk CV Bintang Harapan Kurnia, produk yang sesuai dengan harapan pelanggan CV Bintang Harapan Kurnia, dan rasa senang pelanggan ketika menggunakan produk CV Bintang Harapan Kurnia.

Penelitian menemukan bahwa rata-rata pelanggan merasa kualitas yang ditawarkan perusahaan telah berada pada rata-rata baik dan mampu memberikan kepuasan serta meningkatkan loyalitas pelanggan. Namun evaluasi perlu dilakukan untuk memperbaiki dan meningkatkan mutu melalui peningkatan pada beberapa indikator yaitu kenyamanan pelanggan ketika berada di gerai, ketahanan produk, serta peningkatan kualitas produk secara berkelanjutan. Bagi peneliti selanjutnya, diharapkan agar dapat dapat melakukan penelitian dengan variabel lain di luar model serta dengan cakupan wilayah yang lebih luas.

\section{REFERENSI}

Adhiyanto, M. (2012). Analisis Pengaruh Kualitas Pelayanan terhadap Kepuasan Konsumen Menggunakan Jasa Balai Latihan Kerja Industri (BLKI) Semarang. Fakultas Ekonomika dan Bisnis Universitas Diponegoro.

Aditya, M. P., \& Ni Made Wulandari Kusuma Dewi. (2017). Peran Kepuasan Pelanggan dalam Memediasi Pengaruh Kualitas Pelayanan terhadap Loyalitas Pelanggan. E-Jurnal Manajemen Unud, 6(9), 5061-5087.

Andreas, C. (2016). Pengaruh Kualitas Produk terhadap Loyalitas Pelanggan dengan Kepuasan sebagai Variabel Intervening. Sekolah Tinggi Ilmu Ekonomi Indonesia (STIESIA) Surabaya.

Antanegoro, R. Y., Djasuro Surya, \& Fauzi Sanusi. (2017). Analisis Pengaruh 
Inovasi Produk, Inovasi Layanan. Jurnal Riset Bisnis Dan Manajemen Tirtayasa, 1(2), 167-179. Retrieved from

Chien-Hsiung, L., \& Rd Hsiao-Kang Kaohsiung Taiwan O C Taiwan, S.-H. R. (2011). A Study on The Relations Between The Brand Image and Customer Satisfaction in Catering Businesses. African Journal of Business Management, 5(18), 7732-7739.

Consuegra, D. M., Molina, A., \& Agueda Esteban. (2007). An Integrated Model of Price, Satisfication and Loyalty: An Empirical Analysis In The Service Sector. Jpurnal of Product and Brand Management, 16(7), 459-468.

Familiar, K., \& Ida Maftukhah. (2015). Pengaruh Kualitas Produk dan Kualitas Pelayanan terhadap Loyalitas Pelanggan Melalui Kepuasan Pelanggan. Management Analysis Journal, 4(4), 348-354.

Hidayat, A. T., Mustikasari Elita, F., Setiaman, A., Managemen, J. I., Fakultas, K., \& Komunikasi, I. (2012). Hubungan Antara Atribut Produk Dengan Minat Beli Konsumen. Mahasiswa Universitas Padjadjaran, 1(1), 1-14.

Husein, U. (2003). Metode Riset Perilaku Konsumen Jasa (Ghalia, Ed.). Jakarta.

Kotler, P., \& Keller, K. L. (2009). Manajemen Pemasaran (12th ed.; PT Indeks, Ed.). Jakarta: PT Mncana Jaya Cemerlang.

Lovelock, C., \& Wright L. (2005). Manajemen Pemasaran Jasa (PT Indeks, Ed.). Jakarta: Gramedia.

Natalia, I. (2009). Analisa pengaruh Orientasi Pasar, Kualitas Pelayanan dan Inovasi Produk terhadap Kepuasan Konsumen. Universitas Indonesia.

Nurlina, R. A. (2013). Pengaruh Customers Satisfication Strategy terhadap Peningkatan Kepuasan Konsumen. Forum Ilmiah, 10(2), 172-181.

Prabowo, B. (2008). Pengaruh Relationship Marketing terhadap Loyalitas Pelanggan melalui Kepuasan Pelanggan pada PT Astra Surabaya. Jurnal Ilmu-Ilmu Sosial , 8(2), 92-97.

Putra, F. W., \& Sulistyawati, E. (2018). Peran kepuasan pelanggan memediasi pengaruh kualitas layanan terhadap loyalitas pelanggan (studi kasus pada rumah makan bakmi tungku di kabupaten badung). E-Jurnal Manajemen Universitas Udayana, 7(1), 525.

Putro, S. W., \& Prof. Dr.Hatane Semuel, MS., Ritzky Karina M.R. Brahmana, S.E., M. A. (2014). Pengaruh Kualitas Layanan dan Kualitas Produk terhadap Kepuasan Pelanggan dan Loyalitas Konsumen Restoran Happy Garden Surabaya. Jurnal Manajemen Pemasaran, 2(1), 1-9.

Rahyuda, K., \& Atmaja, J. (2017). Metode Penelitian Bisnis. Denpasar: Udayana University Press. 
Schiffman, L. G., \& Kanuk, L. L. (2006). Consumer Behavior (7th ed.). Jersey: Prentice Hall.

Setiadi, N. J. (2010). Perilaku Konsumen. Jakarta: Kencana Media Prenada Grup.

Sugiyono. (2016). Metode Penelitian Kuantitatif, Kualitatif dan R\&D. Bandung: Alfabeta.

Sukarmen, P., Sularso, A., \& Wulandari, D. (2013). Analisis Pengaruh Inovas Produk terhadap Kepuasan Konsumen dengan Keunggulan Bersaing sebagai Variabel Intervening pada Produk Gula Pasir Sebelas (GUPALAS) Pabrik Gula Sembroro PTP Nusantara XI (Persero). JEAM, 12(1), 64-79.

Sunarto. (2006). Pengantar Manajemen. Bandung: Alfabeta.

Suprapti, N. W. S. (2010). Perilaku Konsumen (Pemahaman Dasar dan Aplikasinya dalam Strategi Pemasaran). Denpasar: Udayana University Press.

Surbakti, N., \& Widyarini, M. (2010). Pengaruh Service Recovery Pada Kepuasan Pelanggan: studi Kasus AUTO2000 Bandung. Jurnal Administrasi Bisnis, $6(1), 22-42$.

Surya, I. P., Wijaya, A., \& Nurcaya, N. (2017). Kepuasan Pelanggan Memediasi Kualitas Produk dan Kewajaran Harga terhadap Loyalitas Merek MCDonalds di Kota Denpasar. E-Jurnal Manajemen Unud, 6(3), 1534-1563.

Sutisna. (2001). Perilaku Konsumen dan Komunikasi Pemasaran. Bandung: Remaja Rosdakarya.

Tefera, O., \& Govender, K. (2017). Service Quality, Customer Satisfaction and Loyalty: The Perceptions of Ethiopian Hotel Guests. African Journal of Hospitality, Tourism and Leisure, 6(2). Tjiptono, F. (2006). Pemasaran Jasa. Malang: Bayumedia Publishing.

uliastina, K., \& Made Jatra. (2014). Pengaruh Kualitas Pelayanan terhadap Kepuasan Konsumen pada L'Amore Cafe di Denpasar. E-Jurnal Manajemen Unud, 3(2).

Utami, A. A., Khasanah, I., \& Manajemen, J. (2016). Analisis Pengaruh Kualitas Produk, Kualitas Pelayanan, dan Citra Merek terhadap Loyalitas Pelanggan melalui Kepuasan Pelanggan. Diponegoro Journal of Management, 5(3), 19.

Yu, Y. T., \& Alison, D. (2000). The Contribution of Emotional Satisfication to Consumer Loyalty. International Journal of Service, 12(3), 234-250.

Zimmerer, T. W., \& Scarborough, N. M. (2008). Kewirausahaan dan Manajemen Usaha Kecil. Jakarta: Salemba Empat. 
E-Jurnal Manajemen, Vol. 8, No. 11, 2019 : 6741-6761 